https://doi.org/10.31470/2706-7904-2021-16-321-325

\title{
ПЕРЕДУМОВИ АКТУАЛІЗАЦЇ̈ ЗАПОЗИЧЕНЬ У СУЧАСНІЙ УКРАЇНСЬКІЙ МОВІ
}

Reasons for Actualization of Borrowings in Modern Ukrainian Language

\author{
Vasyl Shynkaruk \\ Dr. Sc. in Philology, Professor \\ National University of Life and Environmental Sciences of Ukraine \\ vashyn2010@ukr.net \\ https://orcid.org/0000-0001-8589-4995
}

\begin{abstract}
The article analyzes the reasons for the actualization of borrowings in the modern Ukrainian language on economic issues, due to a number of extralinguistic factors. The views of Ukrainian linguists on foreign lexical items are presented, in particular in the mass media discourse. Achieving the goal led to the use of the following methods: descriptive, comparative, contextual-semantic and functional analysis. The purpose of the work is to consider the reasons for the actualization of foreign language vocabulary in the modern Ukrainian language. We conclude that recently a significant part of terms of foreign origin has been actualized in the media, due to changes in the socio-economic sphere, the availability of the Internet, social networks, close interlingual interaction. It was found that the nominations, due to their frequent use in the press, gradually lost the signs of narrow specialization and became clear to non-specialists.
\end{abstract}

Keywords: lexical-semantic processes, extralinguistic factors, borrowings, media discourse.

\section{Вступ Introduction}

Лексико-семантичні зрушення в мові економіки за чисельністю не такі, як в інших семантичних групах слів, адже поняттєвий апарат економічної науки передусім спрямований на забезпечення комунікативних потреб фахівців цієї сфери, що простежуємо в економічних документах, наукових публікаціях спеціалістів та ін. Водночас розвиток економіки, новини цієї галузі цікавлять не тільки її дослідників, а й пересічних громадян. Доказ цього - щоденна наявність інформації в газетній публіцистиці, на спеціально створених сайтах, промови вищого керівництва держави 
про сучасний стан економіки та ін., на основі чого впродовж першого двадцятиріччя XXI століття найчастіше простежуємо певні зміни в мові сучасної економіки.

Мета роботи - розглянути передумови актуалізації іншомовної лексики в сучасній українській мові.

\section{Методи та методики дослідження Methods and Techniques of the Research}

Досягнення мети зумовили використання таких методів: описового із залученням прийомів зовнішньої та внутрішньої інтерпретації - для вияву тенденцій розвитку лексики на тлі соціально динаміки; порівняльного - для визначення сукупності диференційних ознак, контекстуально-семантичного та функційного аналізу для з’ясування комунікативно-прагматичних та стилістичних ознак номінацій.

\section{Результати Results}

По-перше, у медійному дискурсі помітне розширення семантики понять, активізація низки термінів, що пов'язуємо із соціальної динамікою, від якої значною мірою залежить рівень і спосіб життя людей, а також із прийняттям специфічних законів і постанов тощо. По-друге, виникають нові економічні номінації, які часто запозичують 3 інших мов. Віддзеркалення змін у соціально-економічному житті держави, модернізації економіки, розвитку іiі галузевої структури (промисловості, будівництва, сільського господарства, торгівлі, управління, сфери послуг), потреба їхнього наукового вивчення та ін. слугує вагомою передумовою зрушень у межах лексичного фонду економіки. Розбудова українського економічного словника значною мірою відбувається в періоди реформування, зростання чи спаду економіки. Простежуємо явище розширення семантики відомих понять, поповнення новими словами, що засвідчують зв'язок 3 іншими терміносистемами, міжстильову транспозицію, а найбільше - міжмовну взаємодію, наслідком якої є запозичення. I. М. Шелепкова цілком аргументовано наголошує, що існує значний пласт лексичних одиниць як постійний фонд економічної термінології (незалежно від типу економіки). Такі слова виражають базові загальноекономічні поняття й категорії. Водночас нині простежуємо тенденцію до запозичення економічної лексики переважно з англійської мови, що засвідчує наявність прямих і безпосередніх контактів 3 іноземними партнерами (Шелепкова, 2018: 54). Л. М. Архипенко акцентує на найважливіших стадіях засвоєння іншомовних слів у мові-рецепторі, які долає більшість номінацій 
аналізованого різновиду. Зокрема, дослідниця виділяє три такі етапи: (1) початковий, пов'язаний із моментом, процесом запозичення й «вибором способу запозичення: транслітерація, транскрипція. Цьому етапу властиве графічне переоформлення іншомовного слова, перехід від латиниці до кирилиці» (Архипенко, 2003: 83);

(2) поглиблений, коли лексема починає активно функціонувати в мовленні. «На цьому етапі виявляються парадигматичні зв'язки: полісемія, синонімія, антонімія» (Архипенко, 2003: 83); (3) етап повної адаптації, для якого характерна лексикографічна регламентація, тобто така одиниця має дефініцію, набуває лінгвістично аргументованої граматичної інтерпретації, що грунтується на чинних нормах сучасної української літературної мови (Архипенко, 2003: 83). Цілком умотивованим також вважаємо запропоноване дослідницею вирізнення таких типів адаптації: графемно-орфографічного, семантичного, словотвірного, граматичного (Архипенко, 2003: 83-84).

Акцентуючи на динаміці лексичної системи, науковці цілком умотивовано акцентують увагу на екстралінгвальних та інтралінгвальних чинниках цього процесу. До групи перших О.А. Стишов зарахував: посилення глобалізації, вибір Україною європейського шляху розвитку, активізацію співпраці зі світовим співтовариством у низці галузей, зокрема й економіці, участі українських науковців у конференціях, симпозіумах тощо, допомога інших держав, закупівля нових видів техніки й устаткування, навчання українців у розвинених країнах Заходу, загальна демократизація в Україні, зростання рівня освіченості більшості їі громадян, зокрема оволодіння іноземними мовами, мода на іншомовні слова й запозичення, потужний вплив інтернет-телефонії, посилення діяльності іноземних фірм, значний вплив реклами, у якій вагому частку посідають нові іншомовні слова, пожвавлення міграції та ін. Інтралінгвальними чинниками дослідник уважає системність мови, тенденцію до інтеграції іiі елементів, внутрішньомовну потребу в називанні нової реалії, принцип економії мовної енергії, лінгвальних засобів, потребу уточними й розмежувати близькі поняття, прагнення до новизни та свіжості, емоційності й експресивності тощо (Стишов, 2019: 100-102). Виділені О.А. Стишовим різновиди зовнішніх i внутрішніх чинників актуальні й для спеціалізованої економічної лексики, передусім запозичень, що активно їі поповнюють.

Після потрапляння до сфери мовлення фахівців такі одиниці почасти полишають вузькоспеціалізовану сферу вживання й проникають до засобів масової інформації. Поза сумнівом, обсяг номінацій, використаних у наукових публікаціях і в медійному дискурсі соціально-економічної тематики, відрізняється. Професійному економічному мовленню притаманна наявність значної кількості спеціальних категорій, натомість термінологічний апарат мови української публіцистики вужчий, 
що зумовлено адресуванням інформації великій авдиторії, переважна частина якої не $€$ фахівцями в економічній сфері. У газетній публіцистиці автори переважно послуговуються базовими поняттями, прагнучи зробити текст зрозумілим для максимальної кількості реципієнтів, і в разі використання незрозумілого чи малозрозумілого слова зазвичай вдаються до його пояснення.

Тенденції оновлення економічної лексики простежуємо у фінансуванні, кредитуванні, банківській справі, в описах різних процесів, що відбуваються на підприємствах, в організаціях, фірмах і товариствах, у текстах, які віддзеркалюють явища, пов'язані з ціноутворенням, купівлею-продажем, субсидіями тощо.

Проблема опису мовних одиниць на позначення різноманітних економічних понять, процесів, явищ в українській лінгвістиці не нова. Пропри наявність значної кількості напрацювань, вивчення новітньої економічної термінології, засвідченої в періодичних виданнях, не можна вважати вичерпним, адже економічні трансформації постійно відбуваються в сучасному світі, що безпосередньо впливає на мовну динаміку в економічній термінології. Важливим є акцент на активізації понять у певні періоди, формуванні нових значеннєвих відтінків відомих термінів, вияві семантики, граматичних і стилістичних ознак запозичених одиниць цього різновиду, їхній здатності бути дериваційною базою для інших неолексем тощо.

Важливою рисою термінологічної динаміки $є$ поступове спрямування вузькоспеціалізованих понять до групи широковживаних лексем. О.А. Стишов такий потенціал приписує передусім інтернаціоналізмам, що активно потрапляють до українського слововжитку з англійської мови та ії американського варіанта (Стишов, 2003: 65). Виявляючи солідарність із міркуваннями дослідника, зазначимо, що розширення економічного словника завдяки англіцизмам цілком закономірне, воно зумовлене активним процесами глобалізації, а отже й спілкуванням між людьми різних національностей. Для реалізації цих та низки інших питань активно вживають англійську мову.

Акцентуючи на частиномовні інтерпретації термінів економіки, зазначимо, що їхній основний пласт становлять іменники 3 абстрактним значення, рідше трапляються дієслова та прикметники, які зазвичай структурують аналітичні поняття. Оскільки наукових праць, присвячених дослідженню економічної терміносистеми, зокрема іiі семантичних, структурних, частиномовних, дериваційних та інших параметрів, чимало, то в цьому розділі закцентуємо увагу передусім на поняттях, що в лінгвістиці схарактеризовані найменшою мірою й потрапили до медійного вжитку відносно недавно. 


\section{Висновки \\ Conclusions}

Отже, упродовж останнього часу актуалізації в засобах масової комунікації зазнала значна частина термінів іншомовного походження, що зумовлено змінами в соціально-економічній сфері, доступністю інтернету, соціальних мереж, тісною міжмовною взаємодією. Такі номінації завдяки частому вживанню в пресі поступово втратили ознаки вузькоспеціалізованості й стали зрозумілими для нефахівців.

\section{Література References}

Архипенко, Л.М. (2003) Етапи і типи адаптації однослівних англомовних фінансовоекономічних термінів. Культура народов Причерноморья, 44, 83-84.

Стишов, О.А. (2003) Українська лексика кіния ХХ століття (на матеріалі мови засобів масової інформації): монографія. Київ: Вид. центр КНЛУ, 388 с.

Шелепкова, І.М. (2018) Характеристика української економічної термінології на сучасному етапі розвитку. Закарпатські філологічні студії, 7(1), 52-56. 